\title{
The Holocene salinity changes in the southwestern Black Sea: A reconstruction based on dinoflagellate cysts
}

\author{
T.J. Verleye ${ }^{1}$, K. Mertens ${ }^{1}$, S. Louwye ${ }^{2}$, H.W. Arz ${ }^{2}$ \\ ${ }^{1}$ Research Unit Palaeontology, Department of Geology and Soil Sciences, Universiteit Gent, Krijgslaan \\ 281 S8, B-9000 Gent, Belgium \\ ${ }^{2}$ Geo Forschungs Zentrum-Potsdam, Telegrafenberg, 14473 Potsdam, Germany
}

Dinoflagellate cysts are used as a proxy for the reconstruction of the salinity variations during Holocene times in the southwestern Black Sea. Core GeoB 7625-2, located $50 \mathrm{~km}$ northeast of the mouth of the Sakarya River, was sampled with a 200 year time interval between 0.25 ka BP - 7.8 ka BP. In the lower part of the core, some crucial intervals were sampled with a higher resolution for the determination of the reconnection between the Black Sea and the Sea of Marmara. A drastic change in the dinoflagellate cyst assemblage - from a freshbrackish water to saltwater association - is observed between $\sim 9.6$ and $\sim 8.1 \mathrm{ka}$ BP. The fresh to brackish water indicator species are Spiniferites cruciformis form 1-4 and Pyxidinopsis psilata, while the most important saltwater species are Lingulodinium machaerophorum and cysts of Pentapharsodinium dalei. The first occurrence of euryhaline species took place synchronous with a sea level rise and an increase in productivity. The process length of $L$. machaerophorum, a salinity proxy, indicates a gradual salinity increase. This assumes a gradual reconnection between the Black Sea and the Sea of Marmara, which conflicts with the catastrophic flood (Noah's Flood Hypothesis) introduced by Ryan et al. $(1997,2003)$. The 500 to 800 year cycles observed in the sedimentary record by Lamy et al. (2006), and related to the North Atlantic Oscillation, were not only recorded by us in the salinity variations but also in dinoflagellate cyst abundances (productivity). The observed productivity changes are furthermore related to the sedimentation rate: the increase in precipitation in Anatolia possibly results in a higher sediment discharge leading to a better preservation of the organic-walled microfossils. This makes it difficult to determine whether the fluctuations of the dinocysts/gram ratio are the result of fluctuations in productivity or are an artefact due to changes in the sedimentation rate. Furthermore, it is shown that Peridinium ponticum, a species restricted geographically to the Black Sea, is a good proxy for the reconstruction of Holocene salinity variations since its relative abundance fluctuates synchronous with the process length variations of $L$. machaeorophorum. 